\title{
TECHNIQUE FOR THE COMPUTATIONAL DETERMINATION OF THE HYDRAULIC RESISTANCE OF A GAS-DISPERSED FLOW
}

\author{
Institute of Technical Mechanics \\ of the National Academy of Sciences of Ukraine and the State Space Agency of Ukraine \\ 15 Leshko-Popel St., Dnipro 49005, Ukraine; e-mail: knyshenko@ukr.net
}

The aim of this work is to determine the hydraulic resistance of a gas-dispersed flow in a horizontal channel with a minimum of empirical data. Assuming the gas-dispersed flow energy balance as a sum of two terms: the carrier gas energy and the particle energy, a relation for hydraulic resistance determination in Gasterstadt's form is obtained. To find the particle drag and relative velocity appearing in this relation, use is made of the results of a numerical solution of the problem of the motion of particles in a horizontal channel in Lagrangian variables with account for the interaction of the particles with the channel walls and with one another. The effect of the particles on the carrier gas parameters is neglected. A verification of the proposed technique using various empirical relationships reported in the literature has shown that the calculated and the experimental results are in satisfactory agreement. The proposed technique may be used in the development and design of engineering systems with gasdispersed flows.

Keywords gas-dispersed flow, hydraulic resistance, particle, collision, channel wall, numerical calculation, verification.

1. Gasterstadt I. Pneumatic Transport. Experimental Study (in Russian). Leningrad: Publishing House of the Nord-West Regional Industrial Bureau of the Supreme Council of the National Economy, 1927. 119 pp.

2. Zegler G. Agriculture Abroad (in Russian). Moscow: Collected translations, 1954. No. 3. Pp. 117-192.

3. Lobaev B. N. Design of Air Ducts and Fan, Compressor, and Pneumatic Transport Plants (in Russian). Kiev: Stroitelstvo I Arkhitektura USSR, 1959. $197 \mathrm{pp}$.

4. Dzyadio A. M., Kemmer A.S. Pneumatic Transport at Grain Processing Plants (in Russian). Moscow: Kolos,1967. 297 pp.

5. Gorbis Z. R. Heat Exchange and Hydromechanics of Dispersed Through Flows (in Russian), Moscow: Energiya, 1970. $424 \mathrm{pp}$.

6. Smoldyrev A. E. Hydraulic and Pneumatic Transport (in Russian). Moscow: Metallurgiya, 1975. 383 pp.

7. Mikhaelidis E. E. Motion of Particles in a Gas Flow. Mean Velocity and Pressure Loss (in Russian). Teoreticheskie Osnovy Inzhenernych Rasschetov. 1988. No. 1. Pp. 276-288.

8. Shishkin A. S., Shishkin S. F. Examples of Calculations of Gas-Dynamic Processes of Bulk Material Processing (in Russian). Yekaterinburg: Ural Federal University, 2015. 410 pp. URL: http://study.urfu.ru/.

9. Tymoshenko V. I., Knyshenko Ju. V., Shcherbakov V. I. Features of the Effect of the Gas-Dispersed Flow Particle Size on Particle - Channel Wall Interaction (in Russian). Tekhnicheskaya Mekhanika. 2016. No. 3. Pp. 2434.

10. Naumov Yu. A. Particle Dynamics in a Viscous Medium (in Russian). Matematicheskoye Modelirovaniye 2006. V.18, No. 5. Pp. 27-36.

11. Babukha G. L., . Shraiber A. A. Interaction of a Polydisperse Material in Two-Phase Flows (in Russian). Kiev: Naukova Dumka, 1972. 175 pp.

12. Shraiber A. A., Milyutin V. N., Yatsenko V. P. Hydromechanics of Two-Component Flows with a Polydisperse Solid (in Russian). Kiev: Naukova Dumka, 1980. 252 pp.

13. Schlichting H. Boundary-Layer Theory (in Russian). Moscow: Nauka, 1969. 742 pp. 